\title{
SUSCEPTIBILITY OF SOME COTTON VARIETIES TO TETRANYCHUS URTICAE KOCH INFESTATION, WITH REFERENCE TO ITS PREDACOUS MITES AND SPIDERS IN BENI-SUEF GOVERNORATE
}

\author{
TAHA, HASSAN A. ${ }^{1}$, M. R. ABD EL-KADER ${ }^{2}$, \\ M.A. MOSTAFA ${ }^{2}$ and S. A.A. OSMAN ${ }^{1}$
}

1. Plant Prot. Res Institute, A.R.C, Dokki, Giza, Egypt.

2. Fac. Agric. Al-Azhar Univ., Nasr City, Cairo, Egypt

(Manuscript received 28 November 2013)

\begin{abstract}
The populations of the spider mites Tetranychus urticae Koch (different stages) and their natural enemies i.e. predacious mites (families, Stigmaeidae, Tydeidae and Phytoseiidae) and the true spiders (families Saltisidae, Philrodomidae, Miturigidae, Thomisidae, Lycosidae and Araneidae) were studied in Beni Suef governorate during the cotton cultivated seasons, 2010 and 2011.The population differed according to the different sampling dates on the different cotton varities, Giza 80, 90 x ost, Dandra, Giza 83, Giza 89, Giza 90 and Giza 91 varities.The cotton (Giza 90 variety) was the most susceptible to the spider mite infestation in the two seasons, as, it harboured 96.625 and 83.5 mite individuals, per leaf in the seasons 2010 and 2011,respectively. The statistical analysis of obtained data indicated that the least significant differences for different varities were 39.559 and 19.779 in case of season effect. Also, Giza 80 and Giza 83 varities harboured more predacious mites during 2010 (6.5) individuals for each, while each of Giza 80 and Giza 90 harboured during 2011, 6 predacious mites. The average collected numbers of the spiders was 12.25 individuals on Dandra variety during 2010 while on Giza 83 variety during 2011 season was 8.25 individuals. The study indicated that there was generally positive correlation between the two spotted spider mite and their associated natural enemies.
\end{abstract}

\section{INTRODUCTION}

The two-spotted spider mite, Tetranychus urticae Koch, infests cotton fields nearly every year in Egypt and can be considered an important cause of lost revenue to cotton producers. This may be due to high reproductive potential and short generation time. The feeding damage of spider mites, concentrated primarily on the lower surface of the leaves. Under heavy infestation, severe defoliation occurs and leaves become entirely gray, curl, turn brown, and drop off. This decreases the photosynthetic capacity of plants, Kharboutli et al., (2000). Loss of leaves causes shedding of small bolls and may prevent the lint from developing properly in large bolls (Davidson and Lyon, 1979). The damage caused by mites to a cotton crop depends on timing and intensity of the infestation with respect to the crop growth stage, the presence of predators able to suppress infestation, temperature, and other 
factors, Wilson et al., (1981). The Australian cotton industry relies almost exclusively on synthetic insecticides for control of early season pests, Wilson et al., (1998). These insecticides often disrupt natural enemies activity in the field. Potential predators of the two-spotted spider mite, T.urticae, in cotton fields included theridiid spiders, phytoseiid mites, lacewing larvae, predatory thrips, several coccinellid and several Hemiptera. Predation is implicated as a key factor influencing the early season survival of T. urticae. Phytoseiulus persimilis Athias-Henriot is one of the most important predators of tetranychid mites and is widely found on various crops as it is used in IPM in Egypt, El-Sharabasy (2010).Spiders are also effective biological control agents, prey on several pests in agro ecosystem Hodge (1999). They feed on insects, mites, some other arthropods and play important role in pest control. More than 35000 species of spiders have been identified in the world Ghavami et al., (2007). They are carnivorous arthropods, consume a large number of prey and do not damage plants. This study was conducted to throw some lights on the abundance of the two spotted spider mite, Tetranychus urticae Koch and their associated predators on different cotton varities at Beni Suef governorate during the two successive years 2010 and 2011.

\section{MATERIALS AND METHODS}

This work was conducted to study the population fluctuation of the two-spotted spider mite, Tetranychus urticae, predacious mites (Phytoseiidae, Stigmaeidae and Tydeidae) and the spiders (different families e.g. Saltisidae, Philrodomidae, Miturigidae, Thomisidae, Lycosidae and Araneidae) in Beni Suef governorate during the two cotton cultivated seasons, 2010 and 2011. All active forms of the two-spotted spider mite, Tetranychus urticae, and their associated predacious mites, Phytoseiidae, Stigmaeidae and Tydeidae, were recorded per a random square inch per cotton leaf. The spiders were collected by aiding of plant-shaking method. Five cotton plants were shacked over the shaking white cloth $\left(1 \mathrm{~m}^{2}\right)$. The surveyed spiders were kept in glass vials containing $75 \%$ ethyl alcohol and droplets of glycerin. Environmental factors mainly maximum and minimum temperatures were recorded from Agricultural Research Center Metrological Station. Normal agricultural practices were done with no pesticidal treatments throughout the study periods. The present data were subjected to the analysis of variance (ANOVA), and simple correlation coefficient among the population densities and different factors was calculated, Duncan, 1955.

\section{RESULTS AND DISCUSSION}

1- Cotton (Giza 80 variety): As shown in Table (1), the populations of different spider mites Tetranychus urticae Koch and their natural enemies (predacious mites 
and spiders) were differed according to the different sampling dates. During the early season, the population T. urticae different stages was obviously low in numbers 20 and 35 individuals during the first two counting dates of the first season 2010, respectively then sharply increased to reach its highest population level (160 mites) during the last count in late of May of the same season. In 2011, the mite population followed similar trend in the second season 2010 but with low rate, reaching its peak in lat of May (140 mite). On the other hand, predacious mites and the spiders were, appeared in the vibrate numbers during the different counting dates of the study, The highest population of the predacious mites, represented by Stigmaeidae, Tydeidae and Phytoseiidae during the last two counting dates of May (9 mites for both) and the same trend was observed for spiders and represented by 10 and 12 individuals, respectively.

2- Cotton (90 x ost variety): Considering the cotton variety $90 \times$ ost, the highest abundance of the spider mite was noticed during the late of May (140 mites) for the two seasons, (Table 2). On the other hand, the predacious mites recorded its highest abundance in the same counting date but with low number ( 8 \& 12 mites), respectively. Also, the true spiders reached its peak in the late season before the last investigation sample recording 10 spiders during the two study seasons, respectively.

3- Cotton (Dandra variety): As shown in Table (3) the population of $T$. urticae was low in the first count of the two study seasons 2010 and 2011 (12 and 17 different stages, respectively. It then gradually increased to reach its highest level of abundance during the last sampling date of May 135 and 120 mites, respectively. On the other hand, the population of predacious mites was very low in the early sampling dates, then reached its highest abundance during the late dates (8 different predacous mites in both season). Also, true spiders were in numbers all over the counting dates in the first season but being low in the second season

4- Cotton (Giza 83 variety): Table (4) included the appearance of spider mites T. urticae, predacious mites (Phytoseiidae, Tydeidae and Stigmaeidae) and the spiders. The study indicated that, the two-spotted spider mite appeared during all the investigation dates, recording its highest level of abundance during late May 2010 (120 different mite stages) .The results in Table (4) also indicated weekly changes in the population of the predacious mites, spiders and lady birds.

5- Cotton (Giza 89 variety): Data as shown in Table (5) classify the natural infestation of different stages of T.urticae as well as the occurrence of their natural enemies on cotton leaves (Giza-89) varity during the planting seasons 2010 and 2011. The population of the commonest collected species was slight high numbers of the predacious mites and spiders. On the other hand, the spider mite, T. urticae 
was significantly high and reached its highest abundance during 27/5/2010, 130 mite individuals.

6- Cotton (Giza 90 variety): As shown in Table (6), the same trend of the population of $T$. urticae and its associated predacious mites and true spiders was noticed on cotton Giza 90 variety during the two study seasons, 2010 and 2011 . The peak of T. urticae abundance was noticed on 27/5/2010 and 2011 (155 and 125 different movable stages), respectively.The population of the predacious mites (Phytoseiidae, Stigmaeidae and Tydeidae) on this varity was recorded in moderate numbers during the two study seasons reaching its highest levels of abundance on 27/5/2011, 14 and 12 individuals, respectively.

7- Cotton (Giza 91 variety): The population trend of spider mite and their associated natural enemies inhabiting cotton leaves of Giza 91 variety was shown in Table (7). The population of the spider mite was similar to that on the other tested cotton varieties during seasons 2010 and 2011. The peak of T. urticae was noticed on 27/5/2010 (165 different mite stages).The tabulated data in Table (8), showed that the cotton (Giza 90 variety) was highly susceptible to mite infestation more than any other tested varieties in the first season 2010, whereas, it harboured 96.625 mite individuals, while in the second season 2011, Giza 90 was the highly susceptible, as infested with 83.5 mite species. The statistical analysis indicated that the least significant differences for the varieties was 39.559 and 19.779 in case of season effect. The number of collected predacious mites on cotton leaves, Giza 80 and Giza 83 varieties were during 2010 (6.5) individuals for each, while Giza 80 and Giza 90 were the most harboured varieties during 2011 (6 predacious mites for each). The statistical analysis of the obtained data showed L.S.D. at 0.05 level was 2.6676 for effect of cotton varities on predacous mites population and was 1.3338 for effect of the environment factor of season on population (Table 9). Data in Table (10) showed that the average number of the spiders was 12.25 individuals on Dandra variety during 2010 and 8.25 on Giza 83 variety during season 2011. The statistical analysis in table 10 showed that the L.S.D. at 0.05 level was 2.745 and was 1.3727 for the effect of both cotton varieties and the season, respectively on the spider populations on cotton plants at this region. Table (11) denoted that the correlation between the two spotted spider mite and associated natural enemies. The effects of different cotton varieties on the carmine spider mite, Tetranychus cinnabarinus Boisd. was conducted, Sengonca et al., (1986). The effects of these varieties to show the difference mite development, longevity and fecundity were investigated in the laboratory. On leaves of the Egyptian cotton, Gossypium vitifolium, variety Giza 75, both females and males required a longer period to complete development than on the $G$. hirsutum varieties Coker 310 and $\mathrm{MCH} \mathrm{H}$. The largest total progeny per female was observed on the varieties Coker 310 and $\mathrm{MCH} \mathrm{H}$, while the smallest was on the 
varieties Aleppo 1 and Giza 75. The cotton varieties had no effect on the sex ratio of T. cinnabarinus. El-Heneidy et al., (1996) surveyed cotton field for spiders and found that the population of the family Aranidae was highest. Osman and Zohdi (1976) mentioned that Amblyseius gossipi (El-Badry) occured on cotton leaves at times of decreasing the population of phytophagous species. The study of Wilson et al., (1991) addressed the potential impact of natural enemies on the abundance of spider mites, Tetranychus spp., on cotton in the San Joaquin Valley of California. Those natural enemies were predators, including the big-eyed bug, Geocoris pallens Stål and $G$. punctipes (Say), the minute pirate bug, Orius tristicolor (White), and the western flower thrips, Frankliniella occidentalis (Pergande).

Table 1. Population dynamics of Tetranychus urticae Koch and its predacious mites and spiders inhibiting cotton (Giza 80 ) variety during the growing seasons 2010 and 2011.

\begin{tabular}{|c|c|c|c|c|c|c|}
\hline \multirow{2}{*}{$\begin{array}{l}\text { Sampling } \\
\text { date }\end{array}$} & \multicolumn{2}{|c|}{ Spider mite } & \multicolumn{2}{c|}{ Predacious mites } & \multicolumn{2}{c|}{ Spiders } \\
\cline { 2 - 7 } & 2010 & 2011 & 2010 & 2011 & 2010 & 2011 \\
\hline $20 / 4$ & 20 & 15 & 8 & 3 & 5 & 3 \\
\hline $27 / 4$ & 35 & 30 & 4 & 2 & 7 & 4 \\
\hline $5 / 5$ & 70 & 50 & 3 & 4 & 7 & 6 \\
\hline $12 / 5$ & 100 & 80 & 5 & 6 & 12 & 8 \\
\hline $20 / 5$ & 120 & 130 & 9 & 8 & 10 & 10 \\
\hline $27 / 5$ & 160 & 140 & 9 & 12 & 12 & 10 \\
\hline $5 / 6$ & 135 & 115 & 8 & 9 & 11 & 8 \\
\hline $12 / 6$ & 115 & 100 & 6 & 4 & 8 & 5 \\
\hline Total & 755 & 660 & 52 & 48 & 72 & 54 \\
\hline Mean & 94.375 & 82.5 & 6.5 & 6 & 9 & 6.75 \\
\hline
\end{tabular}

Max. Temp. $29.0-38.6$

Min Temp. 14-19.5

Table 2. Population dynamics of Tetranychus urticae Koch and its predacious mites and spiders inhibiting cotton (90 $\mathrm{x}$ ost) variety during the growing seasons 2010 and 2011.

\begin{tabular}{|c|c|c|c|c|c|c|}
\hline \multirow{2}{*}{$\begin{array}{l}\text { Sampling } \\
\text { date }\end{array}$} & \multicolumn{2}{|c|}{ Spider mite } & \multicolumn{2}{c|}{ Predacious mites } & \multicolumn{2}{c|}{ Spiders } \\
\cline { 2 - 7 } & 2010 & 2011 & 2010 & 2011 & 2010 & 2011 \\
\hline $20 / 4$ & 17 & 18 & 2 & 1 & 7 & 4 \\
\hline $27 / 4$ & 40 & 28 & 3 & 1 & 9 & 3 \\
\hline $5 / 5$ & 60 & 45 & 6 & 4 & 8 & 6 \\
\hline $12 / 5$ & 105 & 75 & 7 & 4 & 10 & 10 \\
\hline $20 / 5$ & 115 & 120 & 7 & 9 & 12 & 14 \\
\hline $27 / 5$ & 140 & 140 & 8 & 12 & 10 & 10 \\
\hline $5 / 6$ & 130 & 120 & 5 & 9 & 7 & 8 \\
\hline $12 / 6$ & 100 & 100 & 4 & 7 & 3 & 5 \\
\hline Total & 707 & 646 & 42 & 47 & 66 & 60 \\
\hline Mean & 88.375 & 80.75 & 5.25 & 5.875 & 8.25 & 7.5 \\
\hline
\end{tabular}

Max. Temp. 29.0 - 38.6

Min Temp. 14-19.5 
126SUSCEPTIBILITY OF SOME COTTON VARIETIES TO TETRANYCHUS URTICAE KOCH INFESTATION, WITH REFERENCE TO ITS PREDACOUS MITES AND SPIDERS IN BENI-SUEF GOVERNORATE

Table 3. Population dynamics of Tetranychus urticae Koch and its predacious mites and spiders inhibiting cotton (Dandra) variety during the growing seasons 2010 and 2011.

\begin{tabular}{|c|c|c|c|c|c|c|}
\hline \multirow{2}{*}{$\begin{array}{l}\text { Sampling } \\
\text { date }\end{array}$} & \multicolumn{2}{|c|}{ Spider mite } & \multicolumn{2}{c|}{ Predacious mites } & \multicolumn{2}{c|}{ Spiders } \\
\cline { 2 - 7 } & 2010 & 2011 & 2010 & 2011 & 2010 & 2011 \\
\hline $20 / 4$ & 12 & 17 & 1 & 2 & 14 & 3 \\
\hline $27 / 4$ & 28 & 40 & 3 & 2 & 16 & 5 \\
\hline $5 / 5$ & 80 & 58 & 5 & 3 & 10 & 8 \\
\hline $12 / 5$ & 120 & 90 & 4 & 4 & 12 & 7 \\
\hline $20 / 5$ & 120 & 90 & 6 & 7 & 12 & 12 \\
\hline $27 / 5$ & 135 & 120 & 8 & 8 & 14 & 14 \\
\hline $5 / 6$ & 108 & 105 & 6 & 8 & 12 & 10 \\
\hline $12 / 6$ & 79 & 84 & 4 & 4 & 8 & 6 \\
\hline Total & 682 & 604 & 37 & 38 & 98 & 65 \\
\hline Mean & 85.25 & 75.5 & 4.625 & 4.75 & 12.25 & 8.125 \\
\hline
\end{tabular}

Max. Temp. 29.0 - 38.6

Min Temp. 14-19.5

Table 4. Population dynamics of Tetranychus urticae Koch and its predacious mites and spiders inhibiting cotton (Giza 83 ) variety during the growing seasons 2010 and 2011.

\begin{tabular}{|c|c|c|c|c|c|c|}
\hline \multirow{2}{*}{$\begin{array}{l}\text { Sampling } \\
\text { date }\end{array}$} & \multicolumn{2}{|c|}{ Spider mite } & \multicolumn{2}{c|}{ Predacious mites } & \multicolumn{2}{c|}{ Spiders } \\
\cline { 2 - 7 } & 2010 & 2011 & 2010 & 2011 & 2010 & 2011 \\
\hline $20 / 4$ & 18 & 20 & 7 & 1 & 16 & 3 \\
\hline $27 / 4$ & 32 & 35 & 4 & 1 & 8 & 4 \\
\hline $5 / 5$ & 75 & 60 & 6 & 2 & 9 & 5 \\
\hline $12 / 5$ & 90 & 68 & 5 & 6 & 18 & 12 \\
\hline $20 / 5$ & 95 & 105 & 6 & 7 & 14 & 16 \\
\hline $27 / 5$ & 120 & 135 & 10 & 8 & 12 & 10 \\
\hline $5 / 6$ & 105 & 140 & 8 & 6 & 9 & 9 \\
\hline $12 / 6$ & 90 & 100 & 6 & 5 & 4 & 7 \\
\hline Total & 625 & 663 & 52 & 36 & 90 & 66 \\
\hline Mean & 78.125 & 82.875 & 6.5 & 4.5 & 11.25 & 8.25 \\
\hline
\end{tabular}

Max. Temp. $29.0-38.6$

Min Temp. 14-19.5 
Table 5. Population dynamics of Tetranychus urticae Koch and its predacious mites and spiders inhibiting cotton (Giza 89) variety during the growing seasons 2010 and 2011.

\begin{tabular}{|c|c|c|c|c|c|c|}
\hline \multirow{2}{*}{$\begin{array}{l}\text { Sampling } \\
\text { date }\end{array}$} & \multicolumn{2}{|c|}{ Spider mite } & \multicolumn{2}{c|}{ Predacious mites } & \multicolumn{2}{c|}{ Spiders } \\
\cline { 2 - 7 } & 2010 & 2011 & 2010 & 2011 & 2010 & 2011 \\
\hline $20 / 4$ & 10 & 15 & 1 & 1 & 9 & 5 \\
\hline $27 / 4$ & 36 & 30 & 5 & 3 & 10 & 2 \\
\hline $5 / 5$ & 80 & 65 & 3 & 2 & 12 & 8 \\
\hline $12 / 5$ & 102 & 77 & 6 & 6 & 16 & 12 \\
\hline $20 / 5$ & 100 & 120 & 4 & 6 & 9 & 10 \\
\hline $27 / 5$ & 130 & 130 & 12 & 12 & 14 & 8 \\
\hline $5 / 6$ & 111 & 135 & 8 & 9 & 11 & 7 \\
\hline $12 / 6$ & 95 & 85 & 4 & 8 & 7 & 4 \\
\hline Total & 664 & 657 & 43 & 47 & 88 & 56 \\
\hline Mean & 83 & 82.125 & 5.375 & 5.875 & 11 & 7 \\
\hline
\end{tabular}

Max. Temp. 29.0 - 38.6

Min Temp. 14-19.5

Table 6. Population dynamics of Tetranychus urticae Koch and its predacious mites and spiders inhibiting cotton (Giza 90) variety during the growing seasons 2010 and 2011.

\begin{tabular}{|c|c|c|c|c|c|c|}
\hline \multirow{2}{*}{$\begin{array}{l}\text { Sampling } \\
\text { date }\end{array}$} & \multicolumn{2}{|c|}{ Spider mite } & \multicolumn{2}{c|}{ Predacious mites } & \multicolumn{2}{c|}{ Spiders } \\
\cline { 2 - 7 } & 2010 & 2011 & 2010 & 2011 & 2010 & 2011 \\
\hline $20 / 4$ & 15 & 14 & 1 & 2 & 4 & 4 \\
\hline $27 / 4$ & 40 & 44 & 4 & 3 & 9 & 6 \\
\hline $5 / 5$ & 90 & 55 & 5 & 3 & 10 & 6 \\
\hline $12 / 5$ & 110 & 80 & 4 & 4 & 10 & 10 \\
\hline $20 / 5$ & 105 & 115 & 7 & 4 & 11 & 12 \\
\hline $27 / 5$ & 155 & 125 & 9 & 14 & 10 & 12 \\
\hline $5 / 6$ & 142 & 130 & 8 & 11 & 7 & 7 \\
\hline $12 / 6$ & 130 & 105 & 6 & 7 & 5 & 5 \\
\hline Total & 787 & 668 & 44 & 48 & 66 & 62 \\
\hline Mean & 98.375 & 83.5 & 5.5 & 6.0 & 8.25 & 7.75 \\
\hline
\end{tabular}

Max. Temp. 29.0 - 38.6

Min Temp. 14-19.5 
Table 7. Population dynamics of Tetranychus urticae Koch and its predacious mites and spiders inhibiting cotton (Giza 91) variety during the growing seasons 2010 and 2011.

\begin{tabular}{|c|c|c|c|c|c|c|}
\hline \multirow{2}{*}{$\begin{array}{l}\text { Sampling } \\
\text { date }\end{array}$} & \multicolumn{2}{|c|}{ Spider mite } & \multicolumn{2}{c|}{ Predacious mites } & \multicolumn{2}{c|}{ Spiders } \\
\cline { 2 - 7 } & 2010 & 2011 & 2010 & 2011 & 2010 & 2011 \\
\hline $20 / 4$ & 23 & 12 & 2 & 2 & 5 & 2 \\
\hline $27 / 4$ & 42 & 40 & 6 & 2 & 8 & 5 \\
\hline $5 / 5$ & 80 & 10 & 2 & 3 & 8 & 7 \\
\hline $12 / 5$ & 88 & 85 & 5 & 6 & 9 & 10 \\
\hline $20 / 5$ & 100 & 125 & 5 & 4 & 8 & 14 \\
\hline $27 / 5$ & 165 & 140 & 10 & 8 & 8 & 10 \\
\hline $5 / 6$ & 145 & 119 & 6 & 7 & 5 & 4 \\
\hline $12 / 6$ & 122 & 77 & 4 & 6 & 4 & 3 \\
\hline Total & 773 & 608 & 40 & 38 & 65 & 55 \\
\hline Mean & 96.625 & 76 & 5 & 4.75 & 8.125 & 6.875 \\
\hline
\end{tabular}

Max. Temp. 29.0 - 38.6

Min Temp. 14-19.5

Table 8. Population dynamics of the Tetranychus urticae Koch on different cotton varieties.

\begin{tabular}{|c|c|c|c|c|}
\hline Season & Variety & Mean & S.D. & Average \\
\hline \multirow[t]{7}{*}{2010} & Giza 80 & 94.375 & 52.95 & $(20-160)$ \\
\hline & $90 \times$ ost & 88.375 & 47.79 & $(17-140)$ \\
\hline & Dandra & 85.25 & 51.99 & $(12-135)$ \\
\hline & Giza 83 & 78.125 & 39.19 & $(18-120)$ \\
\hline & Giza 89 & 83.0 & 45.03 & $(10-130)$ \\
\hline & Giza 90 & 98.375 & 50.736 & $(15-155)$ \\
\hline & Giza 91 & 96.625 & 49.65 & $(23-165)$ \\
\hline \multirow[t]{7}{*}{2011} & Giza 80 & 82.5 & 52.00 & $(15-140)$ \\
\hline & $90 \times$ ost & 80.75 & 50.02 & $(18-148)$ \\
\hline & Dandra & 75.5 & 37.81 & $(17-120)$ \\
\hline & Giza 83 & 82.875 & 43.07 & $(20-140)$ \\
\hline & Giza 89 & 82.125 & 46.37 & $(15-135)$ \\
\hline & Giza 90 & 83.5 & 42.78 & $(14-130)$ \\
\hline & Giza 91 & 76.0 & 56.57 & $(10-140)$ \\
\hline
\end{tabular}


Table 9. Population dynamics of the predacious mites on different cotton varieties during the seasons, 2010 and 2011 at Beni-Suef Governorate.

\begin{tabular}{|c|c|c|c|c|}
\hline Season & Variety & Mean & S.D. & Average \\
\hline \multirow{4}{*}{2010} & Giza 80 & 6.5 & 2.65 & $(3-9)$ \\
\cline { 2 - 5 } & 90 x ost & 5.25 & 2.42 & $(2-8)$ \\
\cline { 2 - 5 } & Dandra & 4.625 & 2.42 & $(1-8)$ \\
\cline { 2 - 5 } & Giza 83 & 6.5 & 2.06 & $(4-10)$ \\
\cline { 2 - 5 } & Giza 89 & 5.375 & 3.76 & $(1-12)$ \\
\cline { 2 - 5 } & Giza 90 & 5.5 & 2.75 & $(1-9)$ \\
\cline { 2 - 5 } & Giza 91 & 5.0 & 2.96 & $(2-10)$ \\
\hline \multirow{6}{*}{2011} & Giza 80 & 6.0 & 3.71 & $(2-12)$ \\
\cline { 2 - 5 } & $90 \times$ ost & 5.875 & 4.46 & $(1-12)$ \\
\cline { 2 - 5 } & Dandra & 4.75 & 2.58 & $(2-8)$ \\
\cline { 2 - 5 } & Giza 83 & 4.5 & 3.18 & $(1-8)$ \\
\cline { 2 - 5 } & Giza 89 & 5.875 & 4.0 & $(2-12)$ \\
\cline { 2 - 5 } & Giza 90 & 6.0 & 4.47 & $(2-8)$ \\
\cline { 2 - 5 } & Giza 91 & 4.75 & 2.4 & \\
\hline
\end{tabular}

L.S.D. at 0.05 level $\quad$ For variety $=2.6676$

For season $=1.3338$

Table 10. Population dynamics of the spiders on different cotton varieties during the seasons, 2010 and 2011 at Beni-Suef Governorate.

\begin{tabular}{|c|c|c|c|c|}
\hline Season & Variety & Mean & S.D. & Average \\
\hline \multirow{4}{*}{2010} & Giza 80 & 9.0 & 2.92 & $(5-12)$ \\
\cline { 2 - 5 } & $90 \times$ ost & 8.25 & 1.47 & $(7-12)$ \\
\cline { 2 - 5 } & Dandra & 12.25 & 2.09 & $(10-16)$ \\
\cline { 2 - 5 } & Giza 83 & 11.25 & 3.92 & $(8-18)$ \\
\cline { 2 - 5 } & Giza 89 & 11.0 & 2.87 & $(9.16)$ \\
\cline { 2 - 5 } & Giza 90 & 8.25 & 2.53 & $(4-11)$ \\
\cline { 2 - 5 } & Giza 91 & 8.125 & 1.37 & $(5-9)$ \\
\hline \multirow{6}{*}{2011} & Giza 80 & 6.75 & 2.99 & $(3-10)$ \\
\cline { 2 - 5 } & $90 \times$ 0st & 7.5 & 3.44 & $(3-114)$ \\
\cline { 2 - 5 } & Dandra & 8.125 & 4.16 & $(3-14)$ \\
\cline { 2 - 5 } & Giza 83 & 8.25 & 5.16 & $(3-16)$ \\
\cline { 2 - 5 } & Giza 89 & 7.50 & 3.56 & $(2-12)$ \\
\cline { 2 - 5 } & Giza 90 & 7.75 & 3.44 & $(2-12)$ \\
\cline { 2 - 5 } & Giza 91 & 6.875 & 4.24 & $(2-14)$ \\
\hline
\end{tabular}

L.S.D. at 0.05 level $\quad$ For varity $=2.745 \quad$ For season $=1.3727$

Table 11. Correlation between different factors on the population dynamics of the collected arthropods

\begin{tabular}{|c|c|c|c|}
\hline Arthropods & Factors & Corr. $(r)$ & Slope \\
\hline \multirow{2}{*}{ Spider mite } & Predacious mites & 0.772 & 0.053 \\
\cline { 2 - 4 } & Spiders & 0.563 & 0.05 \\
\hline \multirow{2}{*}{ Predacious mites } & Spider mites & 0.772 & 11.255 \\
\cline { 2 - 4 } & Spiders & 0.5026 & 0.597 \\
\hline \multirow{2}{*}{ Spiders } & Spider mites & 0.563 & 6.905 \\
\cline { 2 - 4 } & Predacious mites & 0.503 & 0.423 \\
\hline
\end{tabular}




\section{REFERENCES}

1. Davidson, R.H. and W.F. Lyon. 1979. Insect Pests of Farm, Garden, and Orchard. Seventh Edition. John Wiley \& Sons, New York. 596 pp.

2. Duncan, D. B. 1955. Multiple range and multiple F. test. Biometrics, 11:1-42.

3. El-Heneidy, A. H., A. A. Ibrahim, Y. H. Fayad, and G. M. Moawad. 1996. Survey and population dynamics of common true spiders in Egyptian cotton fields. Annals Agric. Sc., Moshtohor, Vol. 34 (3). 1177 - 1187.

4. El-Sharabasy, H. M. 2010. Acaricidal activities of Artemisia judaica L. extracts against Tetranychus urticae Koch and its predator Phytoseiulus persimilis AthiasHenriot (Tetranychidae: Phytoseiid). J. of Biopest., 3 (2):514 - 519.

5. Ghavami, S., M. Taghizadeh, G. Amin and Z. Karimian. 2007. Spider (Order Araneae) Fauna of cotton Fields in Iran. J. Applied Biol. Sci. 1 (2): 07-11.

6. Hodge, M. A. 1999. The implications of Intraguild Predation for the Role of Spiders in Biological Control. J. Arachnog., 27(1): 351-362.

7. Kharboutli, M.S., Charles T. Allen, Chad Norton, and Jerry W. Sites. 2000. Efficiency of selected acaricides against spider mites on cotton in Southeast Arkansas. Proceedings of the 2000 Cotton Research Meeting.

8. Osman, A. A. and G. Zohdi. 1976. Suppression of the spider mites on cotton with mass releases of Amblyseius gossipi (El-Badry). Z. Angew. Entomol., 81(1-4): 245-248.

9. Şengonca, S., M. S. Lababidi, and S. Gerlach. 1986. The Effects of Different Cotton Varieties on the Carmine Spider Mite, Tetranychus cinnabarinus Boisd. (Acari: Tetranychidae).Plant Breed. 97 (4): 297-303.

10. Wilson, L.T., F.L. Thomas and V. Maggi. 1981. Presence-absence sampling of spider mite densities on cotton. California Agriculture, July-August, California Systemwide project.

11. Wilson, L. J., L.R. Bauer and D.A. Lally. 1998. Effect of early season insecticide use on predators and outbreaks of spider mites (Acari: Tetranychidae) in cotton. Bull. Entomol. Res 88 (4): 477-488.

12. Wilson, L. T., P. J. Trichilo and D. Gonzalez. 1991. Natural enemies of spider mites (Acari: Tetranychidae) on cotton: Density regulation or casual association? : Environ. Entomol., 20, (3): 849-856. 
حساسية بعض اصناف القطن للاصابة بالعنكبوت الاحمر ذو البقعتين مع الاثارة الى المفترسات

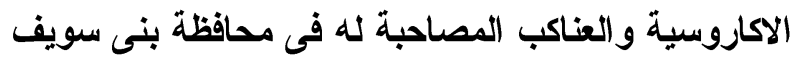

$$
\begin{aligned}
& \text { حسن على احمد طه' - محمد رجائى عبد القادر '- مصطفى عبداللطيف مصطفى ' - } \\
& \text { صدقى عبدالحميد عبدالر اضى عثمان' } \\
& \text { - - معهُ بحوث وقاية النباتات - مركز البحوث النزراعبة - الدقى - جيزة -مصر } \\
& \text { r - كلبة الزراعة - جامعة الازهر - مدينة نصر - القاهرة. }
\end{aligned}
$$

العنكبوت الاحمر العادى Tetranychus urticae Koch و الاعداء الطبيعية المصاحبة لها

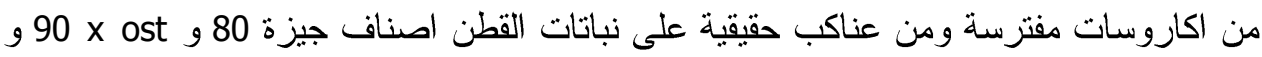

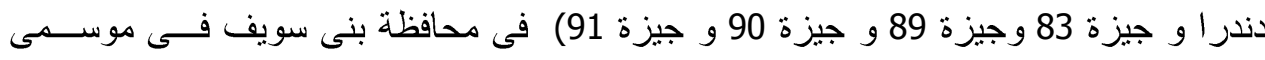

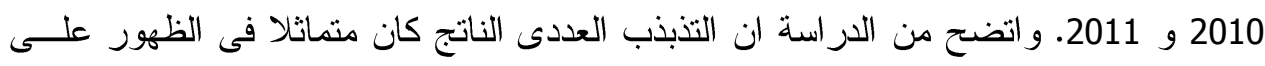

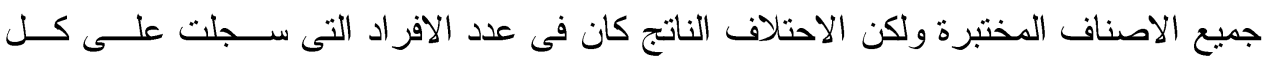

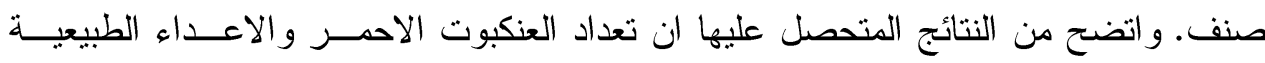

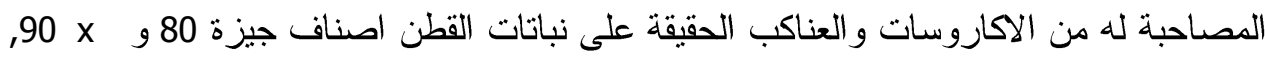
ost

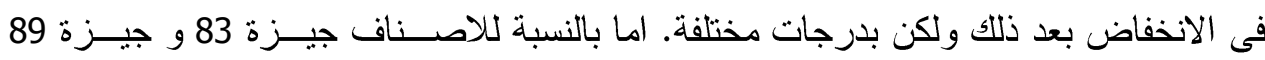

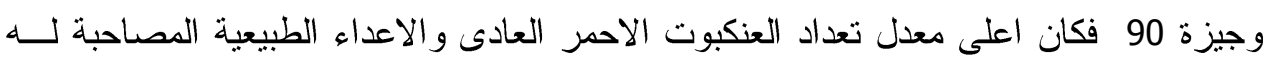
من المفترسات الاكاروسية و العناكب فى بداية شهر يونيو خلال موســمى الدراســــ 2010 و

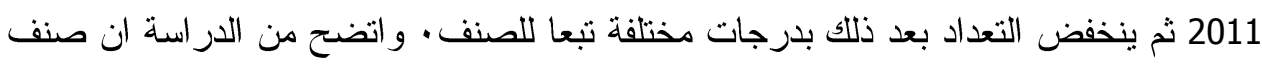

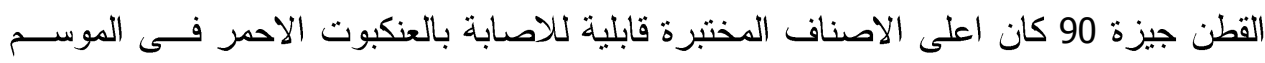

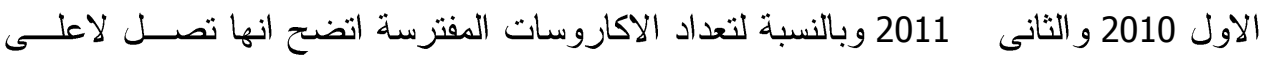

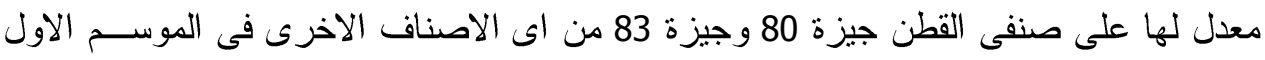

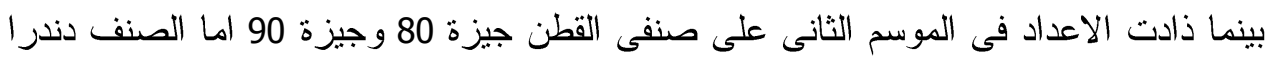
فكان افضل الاصناف لتواجد العناكب الحقيقة فى الموسم الاول والصنف جيزة 83 فى الموسم الثانى •واوضحت الدر اسة ان هنللك ارتباط موجب بين تعداد العنكبوت الاحمــر و المفترســات الاتهـ الاخرى و العناكب خلال موسمى الدر اسة. 